\title{
What Happens to Teachers ICT Attitudes and Classroom ICT Use when Teachers are made to Play Computer Games?
}

\author{
Ruqiyabi Naz. Awan
}

\begin{abstract}
The aim of this research was to investigate how the 'level' of ICT uptake amongst teachers and the 'quality' of ICT use in classrooms can be promoted by challenging teachers' attitudes towards technology adoption. The issue of teachers 'technology confidence' and ICT lesson planning skills were tackled by providing training sessions that focused on encouraging them to use educational multimedia game resources for teaching and learning purposes. The results of this study revealed a positive shift in teachers' attitudes towards the received ICT training and positive attitudes towards the use of ICT in teaching. To encourage greater ICT use by teachers it is suggested that educational game playing workshops (that are aligned to curriculum outcomes) be considered as a form of sustainable in-service training.
\end{abstract}

Index Terms - Computer-games, in service training, teachers ICT attitudes.

\section{INTRODUCTION}

In the past two decades, there has been a concerted push for ICT integration in education [1], [2]. This phenomenon has also been observed in the Arab world and ICT in Education policies have tended to focus on technical aspects of technology deployment and integration rather than pedagogical support [3]. Within the UAE ICT investment costs and expectations of its learning returns have been high in relation to actual ICT use in classrooms [2], [3]. The UAE Ministry of Education is committed to the integration of ICT in its educational system and its recent Education 2020 policy explicitly identified the need for technical and pedagogical training and support to be provided to teachers in public schools.

The use of ICT in Education appears to have created a conflict between those who have a positive or negative attitude to ICT use as a teaching tool [4]. Negative attitudes towards technology have primarily been found to arise due to teachers' lack of confidence in using technology, inadequate pedagogically driven training opportunities being provided, in addition to inadequate technical support [1],[5].

To understand attitudes and their affect on teachers, it is important to understand that 'concerns' form a major part of attitudes. Concerns can be classified as the perceptions, attitudes, motivations, and feelings that teachers experience

Manuscript received October 19, 2011; revised October 30, 2011. This work was supported in part by the Emirates Foundation under Grant \#2009/058.

R. N. Awan is with the British University, Dubai, PO Box 345015, Dubai, UAE (e-mail: Naz.Awan@ buid.ac.ae). when implementing an innovation, in this case 'technology integration' [1]. Research findings appear to suggest that before and during any implementation of any new innovation teachers go through a series of psychological stages regarding their concerns toward the new innovation [1], [4]. Teachers concerns can be arranged in three stages, the first stage concerns the self, the second stage concerns the management and implementation of tasks, and the third is related to concerns about the impact of the innovation on students [1].

The current consensus is that the timely identification of teachers' concerns is a crucial task if technology integration is to be successful in the classroom [5]. The question of interest therefore appears to rest upon whether teachers' attitudes towards ICT can be positively challenged by providing them with supported learning experiences that can then be transferred to develop lessons where ICT use is pedagogically driven and meaningfully integrated to support existing curriculum.

\section{ICT AND TEACHERS}

\section{A. Barriers to ICT Uptake by Teachers}

Early research on technology use in education typically ignored teachers' attitudes and instead focused on the effect computers have on students' attainment, thus failing to recognize the contextual and psychological factors involved in the process of ICT integration into classrooms and curriculum [4].

Research concerning the barriers to ICT use in schools suggests that the reported attitude of teachers towards ICT tells us more about the equipment the teacher has access to, the training they have had, and the sort of teaching and learning community they are part of, than it does about the willingness of the teacher to use ICT [1], [5], [6].

The idea that teachers resist change as a result of their personal beliefs is however questioned by research that suggests that the reported attitude of teachers towards ICT tells us more about the equipment the teacher has access to, the training they have had, and the sort of teaching and learning community they are part of, than it does about the willingness of the teacher to use ICT [1]. Dawes explains that because barriers are closely interconnected, the apparent resistance to change as a barrier is merely a symptom of other barriers to the use of ICT. Schools themselves can also be seen to be resistant to the changes needed to successfully integrate Information Communication Technologies as a result of their organizational structures and if teachers are to 
benefit from ICT in their work and their student's learning; the school environment needs to be supportive of the concept [7].

The British Educational Communications and Technology Agency study (BECTA) [5] also came to similar conclusions suggesting that barriers interrelate and in some cases cause each other (Fig. 1).

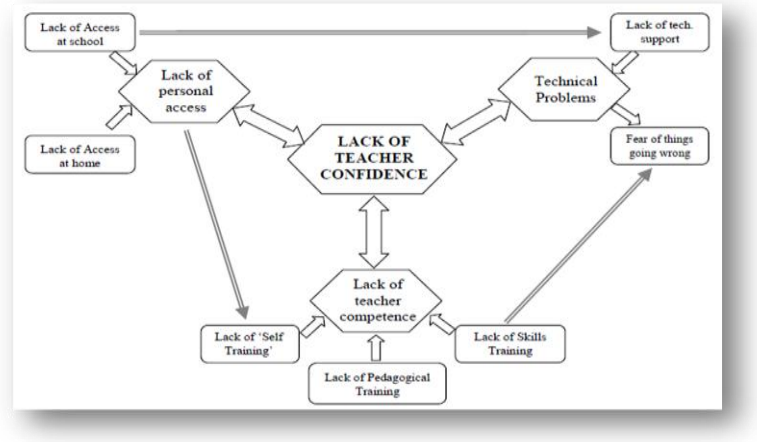

Fig. 1. Relationships between Confidence barrier and other barriers [5].

The external variables characterize outside influences that teachers perceive as affecting their 'ease of use' in working with ICT (TABLE I) [8]

TABLE I: Positive AND NegATIVE FACTORS AFFECTING TEACHERS PERCEIVED’ EASE Of ICT USE’ [10]

\begin{tabular}{|c|c|}
\hline Positive factors & Negative factors \\
\hline $\begin{array}{l}\text { regular use and experience of } \\
\text { ICT outside the classroom }\end{array}$ & $\begin{array}{l}\text { difficulties in using } \\
\text { software/hardware }\end{array}$ \\
\hline ownership of a computer & need more technical support \\
\hline confidence in using ICT & not enough time to use ICT \\
\hline easy to control the class & $\begin{array}{l}\text { is too expensive to use } \\
\text { regularly }\end{array}$ \\
\hline $\begin{array}{c}\text { easy to think of new lesson } \\
\text { ideas }\end{array}$ & $\begin{array}{l}\text { insufficient access to the } \\
\text { resources }\end{array}$ \\
\hline $\begin{array}{c}\text { can get help and advice from } \\
\text { colleagues }\end{array}$ & $\begin{array}{l}\text { restricts the content of the } \\
\text { lessons }\end{array}$ \\
\hline
\end{tabular}

In order for teachers to adopt or use ICT, teachers also need to see the necessity of making such changes and how this affects their practice and student's learning. There are several factors identified which contribute to teachers' perceived usefulness of ICT (TABLE II).

TABLE II: POSITIVE AND NEGATIVE FACTORS INFLUENCING TEACHERS PERCEIVED 'USEFULNESS OF ICT' [8]

\begin{tabular}{|c|c|}
\hline Positive factors & Negative factors \\
\hline $\begin{array}{c}\text { makes my lessons more } \\
\text { interesting }\end{array}$ & makes my lessons more difficult \\
\hline makes my lessons more diverse & makes my lessons less fun \\
\hline has improved the presentation of & reduces pupils' motivation \\
\hline
\end{tabular}

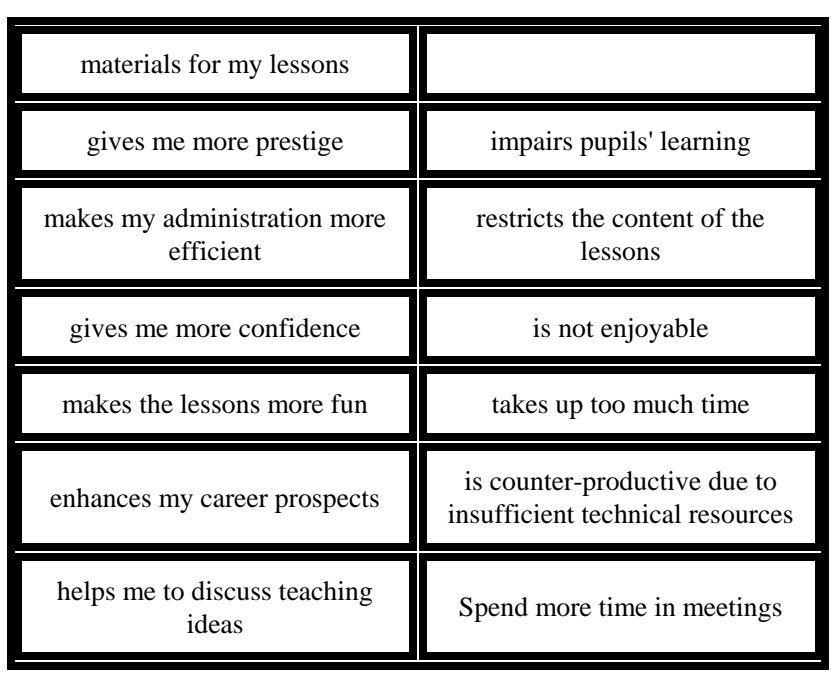

\section{B. The Technology Acceptance Model for ICT}

Computer systems cannot improve organizational performance if they aren't used [9]. The practical question therefore still centers upon how teachers can be assisted in using ICT more frequently and effectively in their classrooms [4]. The Technology Acceptance Model (Fig. 2) may offer one solution as places emphasis on individuals' psychological tendencies and social influences, it assumes that people's actions are mostly rational and that people process the information available to them and act based upon its evaluation. If beliefs and attitudes are drivers for behavior by challenging negative beliefs, attitudes and experiences with positive experiences it should be possible to change subsequent outcome expectations and in the process change attitudes. If ICT could be introduced and used by teachers in a format that generated 'positive feeling's regarding its 'perceived usefulness' and 'perceived ease of use' as a teaching and learning resource, it could be contended that this would assist encouraging positive attitudes towards ICT use as well as actual ICT use in classrooms.

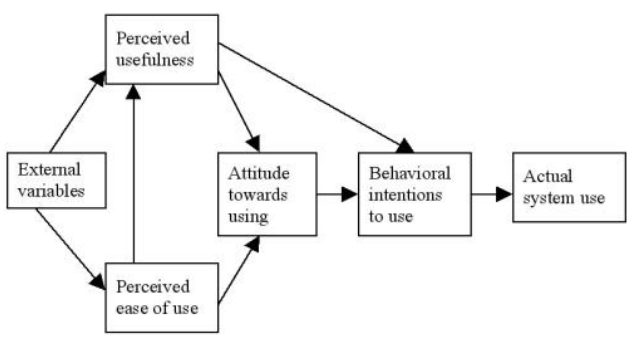

Fig. 2. Technology acceptance model [9]

\section{IMPROVING TEACHERS CONFIDENCE WITH TECHNOLOGY: USING COMPUTER GAMES AS EDUCATIONAL TOOLS}

The impression of much of the mass media is of computer game playing is an activity that offers little or no pedagogic value [10]. Research does however suggest that gaming in its various forms can motivate and interest learners increase the retention of subject material and improve reasoning skills and higher order thinking [11]. The use of a game format for instruction does not however always result in an effective learning environment, as there are several variables involved in creating a successful learning tool. The format should be intrinsically motivating, appropriately challenging, as well as 
offering elements of curiosity, fantasy and control [12]. An activity which is intrinsically motivating is one in which a learner engages in for its own sake, without any external reward or punishment [11]. Research suggests that activities which engage the learner lead to a more thorough knowledge of the subject knowledge at a surface and conceptual level as well as a greater sustained interest in the instructional content [13]. In addition to providing practice and sustaining learner interest, game formats provide opportunities for learners to engage in successful play that require critical thinking, problem solving skills and cognitive learning strategies [14]. These strategies include: organizational strategies (self evaluating, and self monitoring), memory strategies (grouping, imagery, and structured review), and compensatory strategies (understanding the processes involved in making logical, calculated guesses [15]. Game playing is known to be enjoyable and there is a wide variety of educational games now available freely online and commercially available for purchase. One possible way of dealing with teachers confidence issues could be to let them 'play' with these games in order to assess their own knowledge, see what facilities and options are available in game format as well as deciding on formats they as learners like and also their opinions of these games as educational resources.

\section{The PRESENT RESEARCH StUdy}

\section{A. The Schools}

Four single sex public schools in Dubai were randomly selected from the Knowledge and Human Development Agency's (KHDA) list of approved public schools (two cycle one schools and two cycle two schools). One class from each school was selected by the respective Principal to participate in the study.

\section{B. The Teachers}

The four teachers that participated in the study had no experience working with technology in their classrooms. Teachers' perceptions of the available ICT resources available to them and their ICT skills were generally negative. All four teachers described a 'desire' to use technology more in their teaching but felt 'apprehensive' and ill equipped to introduce and incorporate ICT into their teaching. An ICT Skills Audit questionnaire was administered to each teacher in order to identify their ICT skills and to help design a suitable training program me. The questionnaire consisted of 42 questions and covered topics such as Hardware, File Management, Software, Internet and Email. The questionnaire sought to assess teachers' actual experience with technology in general as well as their confidence in their knowledge and ability to use technology effectively within the classroom.

The results of the questionnaire found all four teachers reported having 'limited experience' or 'no experience' on each of the topic areas they were surveyed on (Hardware, File Management, Software, Internet and Email). Furthermore all of the teachers reported having 'little confidence' or 'no confidence' in their knowledge of technology and in their ability to use technology effectively in the classroom.

\section{Increasing Teachers Confidence with Technology: A First Step}

All teachers were enrolled onto an International Computer Driving License course in order to develop their ICT technical and practical skills. In order to address their concerns regarding their noted lack of confidence in their ability to use technology in the classrooms training sessions were organized with the teachers to assist them develop a lesson that would be dealing with the issue of diet and physical activity awareness amongst students as part of a Healthy Schools initiative. All of the teachers in the group were interested in the subject area of 'nutrition education' and perceived this as an important educational subject for their students.

Group training sessions were established and teachers were required to meet once a week for two hours. Within the early training sessions the subject of pedagogically driven ICT use in classrooms was discussed by the researcher and the four teachers were encouraged to peruse the internet looking for useful web sites and games that dealt with the subject of nutrition education that they felt would be suitable for their students. Teachers were asked to engage with the sites they found interesting, play with any interactive games they came across and to make notes on all 'interesting material they came across' so that they could provide the group with feedback at the end of the session regarding their experiences and thoughts on resources as teaching materials. All teachers were required to keep a portfolio of their training sessions in order to assist them find suitable ICT resources that they felt they could use with their students. On the teachers fifth training session, the teachers were introduced to Hot Potatoes. Hot Potatoes is a free web authoring software that enables users to create interactive multiple choice, short answer, jumbled sentence, crossword, matching/ordering and gap fill exercises in an electronic format that can be distributed on a CD ROM, over a network, or via a web page on the World Wide Web. A Hotpot toe visual guide was provided to each teacher to assist the in authoring the software to design their own game. Teachers were encouraged to 'experiment' with Hotpot toe and to keep searching the internet for suitable material and resources for their respective lessons on the subject of healthy eating and physical activity behaviors'. Technical support was provided by the researcher during the training sessions. In week eight teachers were asked to complete another skills audit in order to ascertain their thoughts, beliefs and preferences about ICT usage.

The teachers were not forced to choose a single resource but instead surveyed available material freely available on the internet. A lesson aimed at promoting greater health awareness amongst students was developed by each teacher over the course of the training program me and was delivered to their students in week twelve. Each of the teachers utilized several different ICT resources from online games to downloadable fact and work sheets. Two of the teachers had developed their own quizzes using Hot Potatoes. 


\section{Results}

\section{A. ICT Skills Audit (8 Weeks After Training)}

Eight weeks after the first skills audit, another questionnaire was administered to teachers in order to ascertain their thoughts, attitudes, beliefs and preferences about ICT usage after they had received some training. The survey consisted of 49 items that covered three themes; Training (TABLE III), Use (TABLE IV) and Opinions (TABLE V). Teachers' responses to the 49 items were recorded using a three point scale; Agreed, Disagreed or Neither agree nor disagree.

Table 3 demonstrates that teachers were very receptive and positive to the idea of ICT training. Furthermore the teachers clearly noted the connection between ICT training and its relationship to their teaching practice.

TABLE III: ICT SURVEY - TRAINING STATEMENTS

\begin{tabular}{|c|c|c|c|}
\hline \# & Training statements & Agree & Disagree \\
\hline 1 & I'd like to know more about ICT & 4 & \\
\hline 2 & $\begin{array}{l}\text { I know the basics of ICT but that is } \\
\text { all. }\end{array}$ & 1 & 3 \\
\hline 3 & $\begin{array}{l}\text { I have the appropriate skills to use it } \\
\text { effectively. }\end{array}$ & 3 & 1 \\
\hline 4 & $\begin{array}{c}\text { I am interested in learning more } \\
\text { about using ICT. }\end{array}$ & 4 & \\
\hline 5 & $\begin{array}{c}\text { I need to develop my skills and } \\
\text { knowledge for professional } \\
\text { development. }\end{array}$ & 4 & \\
\hline 6 & $\begin{array}{l}\text { I feel I should develop my skills to } \\
\text { keep up to date with developments } \\
\text { in teaching. }\end{array}$ & 4 & \\
\hline 7 & $\begin{array}{l}\text { I need to develop my skills and } \\
\text { knowledge for the students' benefit. }\end{array}$ & 4 & \\
\hline 8 & $\begin{array}{l}\text { I'm interested and training seems to } \\
\text { be available. }\end{array}$ & 4 & \\
\hline 9 & $\begin{array}{l}\text { I would like to develop my skills } \\
\text { and knowledge in ICT as everyone } \\
\text { else is. }\end{array}$ & 4 & \\
\hline 10 & ICT training is a priority for me. & 4 & \\
\hline 11 & $\begin{array}{l}\text { I feel ICT training is appropriate to } \\
\text { my teaching. }\end{array}$ & 4 & \\
\hline 12 & I find training courses in ICT useful. & 4 & \\
\hline 13 & $\begin{array}{c}\text { I really want to know more about } \\
\text { developing my skills in ICT. }\end{array}$ & 4 & \\
\hline
\end{tabular}

TABLE IV suggest that the teachers opinions of ICT use in their teaching are positive, they feel more confident in using the technology for finding resources for teaching purpose, feel it can assist students in their learning, as well as assist them in organizing their work. Items 15, 20 and 21 suggest that the 'fear' factor associated with teaching with computing technology appears to have subsided (item 20), and that making mistakes is part of the learning process (item 3 ).

TABLE IV: ICT SURVEY - USE STATEMENTS

\begin{tabular}{|c|c|c|c|c|}
\hline 14 & Use statements & Agree & Neither & Disagree \\
\hline 15 & $\begin{array}{c}\text { I use it effectively myself and } \\
\text { I know how to teach the } \\
\text { pupils to use it. }\end{array}$ & 3 & 1 & 3 \\
\hline 16 & $\begin{array}{c}\text { I prefer using it on my own } \\
\text { when no-one is around to see } \\
\text { me make mistakes. }\end{array}$ & 1 & 4 & \\
\hline 17 & $\begin{array}{c}\text { I find it easy to select } \\
\text { appropriate ICT resources for } \\
\text { my teaching. }\end{array}$ & $\begin{array}{c}\text { I feel supported in my use of } \\
\text { ICT. }\end{array}$ & 4 & \\
\hline
\end{tabular}

\begin{tabular}{|c|c|c|c|c|}
\hline 18 & $\begin{array}{c}\text { ICT encourages pupils to } \\
\text { work together collaboratively }\end{array}$ & 3 & 1 & \\
\hline 19 & Computers don't scare me. & 4 & & \\
\hline 20 & $\begin{array}{l}\text { I can cope with all the ICT } \\
\text { jargon. }\end{array}$ & & & 4 \\
\hline 21 & $\begin{array}{l}\text { Systems are slow; it would be } \\
\text { quicker to use a book. }\end{array}$ & & & 4 \\
\hline 22 & $\begin{array}{l}\text { I can always find something } \\
\text { relevant for my students. }\end{array}$ & 4 & & \\
\hline 23 & $\begin{array}{l}\text { I need to use ICT in my } \\
\text { teaching. }\end{array}$ & 4 & & \\
\hline 24 & I think it's necessary. & 4 & & \\
\hline 25 & $\begin{array}{l}\text { ICT helps me find plenty of } \\
\text { relevant information for my } \\
\text { teaching }\end{array}$ & 4 & & \\
\hline 26 & $\begin{array}{l}\text { I manage information more } \\
\text { effectively because of ICT. }\end{array}$ & 4 & & \\
\hline 27 & It makes my work easier. & 3 & 1 & \\
\hline 28 & $\begin{array}{l}\text { ICT helps pupils acquire new } \\
\text { knowledge effectively. }\end{array}$ & 3 & 1 & \\
\hline 29 & $\begin{array}{c}\text { It cuts down my preparation } \\
\text { time }\end{array}$ & 4 & & \\
\hline 30 & $\begin{array}{l}\text { ICT helps me communicate } \\
\text { with colleagues. }\end{array}$ & 3 & & 1 \\
\hline
\end{tabular}

TABLE V: ICT SURVEY - OPINION STATEMENTS

\begin{tabular}{|c|c|c|c|c|}
\hline & Opinion statements & Agree & Neither & Disagree \\
\hline 31 & $\begin{array}{l}\text { I find it helpful for non-work } \\
\text { related tasks. }\end{array}$ & 3 & 1 & \\
\hline 32 & $\begin{array}{l}\text { The pace of technology is too } \\
\text { fast for me. }\end{array}$ & & 1 & 3 \\
\hline 33 & $\begin{array}{l}\text { ICT distracts students from } \\
\text { the subject material. }\end{array}$ & & & 4 \\
\hline 34 & $\begin{array}{l}\text { I'm interested as I suppose I } \\
\text { should be. }\end{array}$ & 4 & & \\
\hline 35 & $\begin{array}{l}\text { I'm interested and have the } \\
\text { time. }\end{array}$ & 4 & & \\
\hline 36 & $\begin{array}{l}\text { I'm interested and have } \\
\text { access. }\end{array}$ & 4 & & \\
\hline 37 & $\begin{array}{c}\text { I feel my skills and } \\
\text { knowledge in ICT are } \\
\text { adequate to teach with }\end{array}$ & 4 & & \\
\hline 38 & $\begin{array}{l}\text { I've got information } \\
\text { overload. }\end{array}$ & 1 & 1 & 2 \\
\hline 39 & $\begin{array}{c}\text { I find using ICT time } \\
\text { consuming. }\end{array}$ & 2 & 1 & 1 \\
\hline 40 & $\begin{array}{l}\text { Pupils can get distracted by } \\
\text { all the technology. }\end{array}$ & 3 & 1 & \\
\hline 41 & $\begin{array}{l}\text { I don't feel lost in the } \\
\text { information age. }\end{array}$ & 4 & & \\
\hline 42 & $\begin{array}{l}\text { I need ICT skills to progress } \\
\text { in the profession. }\end{array}$ & 4 & & \\
\hline 43 & I need to learn about ICT. & 4 & & \\
\hline 44 & $\begin{array}{l}\text { I am interested personally and } \\
\text { developing my skills and } \\
\text { knowledge in ICT is } \\
\text { appropriate to my teaching. }\end{array}$ & 4 & & \\
\hline 45 & I can do fine without it. & & & 4 \\
\hline 46 & I'm glad it was invented. & 4 & & \\
\hline 47 & $\begin{array}{l}\text { My school has a positive } \\
\text { attitude to ICT use. }\end{array}$ & 4 & & \\
\hline 48 & $\begin{array}{l}\text { It seems to motivate the } \\
\text { students to learn. }\end{array}$ & 4 & & \\
\hline 49 & $\begin{array}{l}\text { ICT swamps students with } \\
\text { information. }\end{array}$ & 1 & & 3 \\
\hline
\end{tabular}

Teachers opinions of ICT on this part of the questionnaire (TABLE V) suggests an understanding of balance of good ICT based subject content and learning activities against overwhelming the learner with too much ICT based information that is distracting. There is also an 
acknowledgement that ICT development is perceived as an important part of teachers professional development and that the teachers within this limited sample felt their school was positive in its attitude towards ICT use.

\section{B. The Teaching Experience of Working With the Interactive Games - Teacher Feedback}

After each teacher and class had worked with the ICT resource the researcher asked the teachers of their opinions of the ICT resource and any feedback they had regarding the materials, content and lesson. Analyses of the teacher feedback revealed two key themes concerning the cultural suitability of the games as teaching and learning resources and the games role in promoting cognitive engagement

Teachers' comments touched upon the cultural suitability and appropriateness of the visual material used in the games and the subject matter presented to students:

"Culturally, I think that the material presented in the game is appropriate for the students in my class".

"I checked through the material and found that I could use the whole game as there was nothing I needed to change or modify. Sometimes we need to be careful of the content as we are working with young learners and 'we' know that the internet and computer games can sometimes have content that is not suitable for children and even adults"

"I made sure the content was OK to use with my students, there was nothing I was concerned about, nothing that would be inappropriate or that would be offensive".

Teachers positively commented on the value of the resource as a teaching and learning tool:

"I think that the boys were really excited about this program. They all wanted to answer each question. The reason why is perhaps because it's quite easy and straight forward".

"I think that this program is very suitable for all students despite their differences in age and cognitive ability. I also think that this program enables students to act independently and try to find answers to questions. In addition, I like the way students would learn independently through the excellent feedback or facts after each answer".

"I think that the program is excellent in many ways. It easy to use because of the games structure, clear instructions and a clear pattern in the way students should answer and interact with the game."

\section{DISCUSSION}

The results of this study demonstrate that providing teachers with training and positive learning experiences can positively affect their attitudes towards ICT training and ICT use in their lessons. Follow up feedback from the teachers suggested that they had found the training useful, enjoyed the lesson they had delivered and would appreciate further mentoring in developing their ICT skills and resources further.

In spite of the investments in schools and the diverse initiatives taken by various governments, ICT uptake has been disappointingly slow [4], [8]. Much of the focus of ICT integration in education has focused on the tool rather than the actual users [16]. The present study demonstrates that the training needs of teachers cannot be overlooked when developing initiatives aimed at changing teaching and learning practices in schools and classrooms.

An approach that favors equipping teachers with solely technical skills such as the ICDL appears to operate on a premise that the mere exposure to ICT is insufficient to ensure that learning occurs [7]. Research shows that teachers need to have more than a technical framework within which to structure the use of ICT in teaching and learning. There is a clear understanding by teachers that ICT can be beneficial to their learners but that the use of technology must not be solely mandated to the development of technical skills in students but instead used in a pedagogically meaningful manner within the given subject area. Mumtaz [4] highlights that the most important factors are 'teachers beliefs regarding what should be taught in the curricula (content) and the way in which their subjects should be taught (pedagogy)." Teachers tend not to change their teaching styles when introducing ICT but instead modify their existing practice to incorporate the new use technology [1].

Assessment methods are also a complex issue which may confuse the efforts to measure the value of educational games as teaching and learning materials [16]. The most difficult issue in the assessing the impact of computer based educational games is that many of them foster the learning of 'implicit' as opposed to 'explicit' knowledge. The problem with implicit learning is that learners cannot describe or readily demonstrate the benefits received from an activity even when real benefits are achieved [17].

The question that therefore readily emerges concerns why computer based educational games, have failed to make serious headway as a credible teaching tool in most schools. A number of reasons have been put forward and they suggest: the games have been too simplistic in comparison to competing video games; the tasks are repetitive, i.e. continually doing sums and thus quickly become boring and 'work'; the tasks are poorly designed and do not support progressive understanding; the target audience become aware that it is being coerced into 'learning' in possibly a patronizing manner [18].

With the advent of the internet and wireless technologies the conception of learning as a classroom based activity is rapidly disappearing. Furthermore, the identification of 'play' as an important and valuable component in the learning process has changed the manner in which we conceive 'appropriate' learning activities and materials. Perhaps the challenge for the gaming industry and those wishing to use ICT to assist in the teaching and learning process is to accept that it is important for both students and teachers to be provided with a fun, playful environment where they have a sense of their own progression and where learning is relevant, appropriate and suitably explicit. The present research demonstrates that if the focus of ICT use by teachers in classrooms can be assessed and understood as the meaningful use of the technology in line with pedagogic and teaching objectives, rather than on the 'mastering the technology' itself as a goal, then ICT through the use of 
educational computer games can serve as a personal and professional enabling and empowering tool.

\section{CONCLUSION}

The small sample size makes it difficult to offer any generalizations concerning robustness of the observed results. This study does however highlight that the success of the training was structured around two firm principles, firstly to increase teachers' confidence with technology and secondly, to allow teachers to develop lessons that utilized ICT resources to be pedagogically meaningful for their learners. The observed outcomes of this study found that teachers felt confident and happy with the ICT they were using in their classroom and this resulted in positive learning experiences and attitudes to further ICT training and use in their lessons. This study highlights the need for further research to be conducted assessing how best to assist teachers develop their ICT skills in order to enable greater ICT use in government schools in Dubai.

\section{ACKNOWLEDGMENT}

The author would like to thank Emirates Foundation for providing research funding for this project. In addition the author would also like to extend her thanks to the children, teachers and principles who participated in this project. Finally, the author would like to thank Miss Maitha Bin Shahdoor for her valuable assistance in collecting data and translating materials.

\section{REFERENCES}

[1] T. A. Haydn, T. A and R. Barton, R. Common needs and different agendas: How trainee teachers make progress in their ability to ICT use in subject teaching. Some lessons from the UK. Computers and Education, 2007, 49 (4): 1018-1036.

[2] V. Makrakis. Strategic Planning for Information and Communication Technologies in Education. The case of the United Arab Emirates. In A. Dimitracopoulou (Ed.), Information and Communication Technologies in Education. Athens: Kastaniotis Press, 2002.

[3] V. Makrakis. Training Teachers for New Roles in the New Era: Experiences from the United Arab Emirates ICT Program. Conference Proceedings of the 3rd Panhellenic Conferences. Didactics of Informatics. A. Jimoviannis (ed.) University of Peloponnese, Korinthos, Greece, 2005, pp. 38-57.

[4] S. Mumtaz. Factors affecting teachers' use of information and communication technology: a review of the literature, Technology, Pedagogy and Education. Journal of Information Technology for Teacher Education, 2000, 9 (3): 319-342.

[5] British Educational Communications and Technology Agency (BECTA). A Review of the research literature on barriers and uptake of ICT by teachers. (2004). [online] Available from http://partners.becta.org.uk/page_documents/research/barriers.pdf [Accessed 20 April 2009].

[6] P. A. Ertmer. Teacher pedagogical beliefs: The final frontier in our quest for technology integration. ETRandD, 2005, 53(4):25-39.

[7] M. Cox., C. Preston., and K. Cox. What factors support or prevent teachers from using ICT in their classrooms? 1999, [online] Available from: http://www.leeds.ac.uk.educol/documents/00001304.htm [Accessed on 21 April 2009].

[8] F. D. Davis., Bagozzi, R. P., and Warshaw, P. R. User acceptance of computer technology: A comparison of two theoretical models. Management Science, 1989, 35(8): 982-10003.

[9] M. Papastergiou. Digital game-based learning in high school computer science education: Impact on educational effectiveness and student motivation. Computers and Education, 2009, 52(1):1-12.

[10] T. De Jong., and R. W. Joolingen. Scientific discovery learning with computer simulations of conceptual domains. Reviews of Educational Research, 1998, 68(2):179-201.

[11] E. L. Serrano. The evaluation of food pyramid games, a bilingual computer nutrition education programme for Latino youth. Journal of Family and Consumer Sciences Education, 2004, 22(1):1-16.

[12] D. H., Jonassen., C. Carr., and H. P. Yueh. Computers as mindtools for engaging learners in critical thinking. TechTrends, 1998, 43(2):24-32.

[13] H. Tuzun., M. Yilmaz-Soylu., T. Karakus., Y. Inal., and G. Kizilkaya. The effects of computer games on primary school students achievement and motivation in geography learning. Computers and Education, 2009, 52(1):68-77.

[14] K. Kreisel. Evaluation of a computer based nutrition educational tool. Public Health Nutrition, 2004, 7(2):271-277.

[15] R. Rosas., R., M. Nussbaum., M., P. Cumsille., V. Marianov., M. Correa., P. Flores., V. Grau., F. Lagos., X. Lopez., V. Lopez., P. Rodriguez., and M. Salinas. Beyond Nintendo: design and assessment of educational video games for first and second grade students. Computers and Education, 2003, 40 (1), 71-94.

[16] T. De Jong., and W. R. Van Joolingen. Scientific discovery learning with computer simulations of conceptual domains. Educational Research, 1998, 68 (2), 179-201.

[17] A. McFarlane., A. Sparrowhawk., and Y. Heald, Y. Report on the educational use of games. Teacher evaluating educational multimedia. Accessed from www.teem.org.uk. Accessed on $14^{\text {th }}$ January 2008

[18] Y. Liu., P. Theodore, P. and E. Lavelle. Experimental effects of online instruction on teachers concerns about technology integration. International Journal of Instructional Technology and Distance Learning [online] Available from: http://itdl.org.jounal/Jan_04/article03.htm. [Accessed 1 March 2009] .

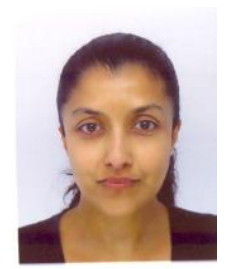

R. N. Awan is Assistant Professor at the Faculty of Education at the British University in Dubai. She is responsible for leading the Information and Communication Technology (ICT) in Education stream of the Masters programme. Dr Awan holds a $\mathrm{PhD}$ from the University of Portsmouth, U.K. Her research focuses how technology is used, and can be used, to and facilitate formal and informal learning,

as well as understanding the role and function of technology in individuals everyday lives. She has teaching experience gained in the UK, Belgium, Japan and the United Arab Emirates and has conducted e-learning policy research for the European Commission. 